Brit. J. industr. Med., 1954, 11, 269.

\title{
A SOCIAL AND OCCUPATIONAL STUDY OF THE CAUSES, COST, AND PREVENTION OF INFECTIONS OF THE HAND
}

\author{
BY \\ RUTH WILKES \\ From the Nuffield Department of Industrial Health (University of Durham), \\ King's College, Newcastle-upon-Tyne
}

(RECEIVED FOR PUBLICATION JUNE 18, 1954)

\begin{abstract}
Although there are many books and papers dealing with the treatment of hand infections and also with the bacteriology of wound infection and sepsis, little has been published about the social and occupational aspects of hand infections.

In this study the following questions were considered: What is the cost of a hand infection, measured in terms of money and working time lost by the patient? What part do social and occupational factors play in the origin and development of sepsis? How can infections of the hand be prevented?
\end{abstract}

\section{Method}

The patients concerned in this enquiry were all attending the hand clinic of the department of surgery in the Royal Victoria Infirmary, Newcastleupon-Tyne. All casualties are first reported to the accident room of the hospital where minor lacerations are dealt with, but all serious hand injuries or infections are referred to the hand clinic. Dormitory accommodation is provided in a hostel attached to the clinic, and almost all the adult patients are admitted to the hostel, where, on the average, they stay for three days for infections and seven days for injuries.

The research included injuries as well as infections of the hand, but this report is concerned only with hand infections, and data compiled from the injuries research are not mentioned except for purposes of comparison. When comparisons are made the groups will be distinguished by referring to the injuries as the "trauma group" and the infections as the "sepsis group".

The patients were all men of working age, and they were interviewed in the hostel during 27 of the weeks in the period beginning March, 1952, and ending midDecember, 1952. The total number of patients with infected hands (and fingers) interviewed during that period was 151 . Of these, $106(70 \%)$ gave a definite history of injury (sepsis following injury), while 45 $(30 \%)$ could not remember an injury to the hand before the onset of infection (sepsis but no known trauma). In the interests of accuracy, patients were asked to state when and how the injury occurred, with relevant dates, and patients who could not remember an injury but thought that they must have injured the hand were classified with the patients giving no history of injury. Patients were not selected ; all the new patients who were in the hostel during the weeks of interview were seen.

Direct questioning was avoided as far as possible. Once the factual information relating to dates, times, and incomes had been obtained, the interview became a discussion on how the patient's particular hand infection had occurred, and also on the general problem of industrial sepsis. The information was recorded on a schedule which had been designed to cover the main points of the enquiry.

Limitations of Method.-One of the most important limitations of the method concerned the difficulty people have in remembering the details of any event in their lives occurring more than a week or two before. Care was taken to guard against errors from this source, and in cases of obvious confusion patients were asked to trace the history of their illness with the aid of a diary. Fortunately, histories did not often go far back, and there is no reason to suppose that most of the dates given were not accurate, but where there was doubt about the dates given they were classified as date unknown.

Again, much of the interesting and valuable information consisted of patients' opinions-as, for example, that on first-aid facilities and the use of safety gloves-and could not be described numeri- 
cally. The data here are necessarily nebulous, but not valueless on that account. In general, the study was made from the point of view of the patient, and there is no evidence to suggest that patients have evaded the issue or not given an honest opinion. It is possible that some patients tended to underestimate the interval from injury or onset of infection to first treatment ; but this is regarded as unlikely, partly because exact dates were always asked for, and partly because it is reasonable to suppose that after one or two sleepless nights caused by the discomfort of an infected hand the patient would seek treatment as soon as possible.

\section{Results}

The Diagnoses.-Most of the patients who attend the clinic have well-established infections, and all those who were interviewed had infections severe enough for them to stay for a few days in the hostel. The diagnoses of the patients are set out in Table 1.

TABLE 1

MEDICAL CLASSIFICATION OF THE INFECTIONS

\begin{tabular}{|c|c|c|c|c|c|c|}
\hline \multirow{3}{*}{ Type of Infection } & \multicolumn{6}{|c|}{ Number of Patients } \\
\hline & \multicolumn{2}{|c|}{$\underset{\text { Sepsis }}{\text { Traumatic }}$} & \multicolumn{2}{|c|}{$\underset{\text { traumatic }}{\text { Non- }}$} & \multicolumn{2}{|c|}{ Total } \\
\hline & No. & $\%$ & No. & $\%$ & No. & $\%$ \\
\hline 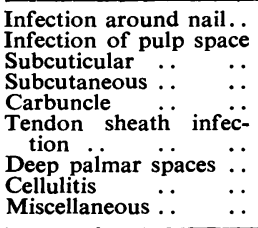 & $\begin{array}{r}14 \\
19 \\
1 \\
52 \\
- \\
1 \\
8 \\
2 \\
9\end{array}$ & $\begin{array}{l}13 \\
18 \\
1 \\
49 \\
- \\
1 \\
8 \\
2 \\
8\end{array}$ & $\begin{array}{r}10 \\
10 \\
3 \\
13 \\
1 \\
1 \\
3 \\
1 \\
3\end{array}$ & $\begin{array}{r}22 \\
22 \\
7 \\
29 \\
2 \\
2 \\
7 \\
2 \\
7\end{array}$ & $\begin{array}{r}24 \\
29 \\
4 \\
65 \\
1 \\
2 \\
11 \\
3 \\
12\end{array}$ & $\begin{array}{r}16 \\
19 \\
3 \\
43 \\
1 \\
1 \\
7 \\
2 \\
8\end{array}$ \\
\hline Total & 106 & 100 & 45 & 100 & 151 & 100 \\
\hline
\end{tabular}

In both the traumatic and non-traumatic groups most of the infections were subcutaneous, infections of the pulp space, and infections around the nail.

Nearly all the patients had had treatment of some kind before attending the clinic, the majority being sent up by their doctors. Occasionally a patient came up on his own initiative, but this was unusual. The remainder of the patients were sent to the clinic by other hospitals or by industrial first-aid departments.

The Occupations of the Patients. - To what extent are infections of the hand related to occupation? If infection is attributed to injury, how was the injury caused and is it a hazard of some particular occupation? If the infection has no history of injury, is it nevertheless related to some type of employment?

Not all the injuries occurred at work, and Table 2 includes 18 patients $(17 \%)$ in the sepsis group who
TABLE 2

OCCUPATIONS OF THE PATIENTS

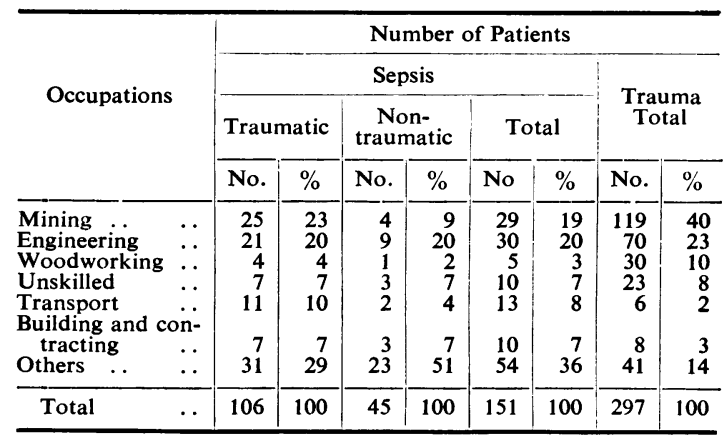

were injured away from work, usually at home. For purposes of comparison Table 2 also includes figures relating to the trauma group of patients. Unfortunately the figures, especially for the group with sepsis unrelated to injury, are extremely small, but one or two points are worth making. An interesting point, also noted by Robins (1952), is that mining accounted for a far higher proportion of the injuries than of the infections. Forty per cent. of the patients in the trauma group were miners compared with only $19 \%$ of the patients with infected hands. Of the 29 miners with infected hands, nearly a quarter (seven patients) were datal (day rate) workers, and the rest worked in a variety of jobs, mostly at the coal face.

The other large occupational group was engineering, and this was expected, partly because nearly a quarter of the adult males on Tyneside work in the engineering industries, and partly because men working in these industries are exposed to the kind of trivial injury which, it is known, often leads to infection. The Registrar-General's Classification of Occupations, 1950 (General Register Office, 1951), has been used throughout this study, and in this classification engineering and allied trades covers a large number of different trades, including some shipyard workers (but not labourers). No one group within engineering was noticeably larger than any of the others, but the men were all doing jobs where they might easily knock, cut, or blister their hands, or where there was danger of injury from metal filings. Unskilled workers, and workers in transport and communication, and in building and contracting, made up between them $22 \%$ of the total.

Data from the trauma group have been included in the last column of Table 2, so that a comparison can be made between the two groups of patients, and it will be seen that there is a striking difference in the distribution of occupations between the two groups. 
Only $14 \%$ of the total number of patients in the trauma group were in occupations listed under "Others" (11 different occupations), whereas the patients in the sepsis group mentioned so great a variety of jobs that the classification "Others" includes 16 different occupations and comprises $36 \%$ of the total. Seven was the largest number of patients included in any one of these occupations, but usually there were no more than three or four patients in each group, and sometimes only one. The most frequently mentioned occupations were personal service (chefs, chimney sweeps, etc.), agriculture, clerical work, metal manufacture, makers of food or drink, and printing. Six of the men were unemployed.

How the Injury was Caused.-Table 3 very clearly brings out the smallness of the injury which led to the infection. This Table includes only the injuries

TABLE 3

CAUSE OF THE INJURY

\begin{tabular}{|c|c|c|c|c|c|c|c|c|c|c|}
\hline \multirow{3}{*}{ Injury Caused by } & \multicolumn{10}{|c|}{ Number of Patients } \\
\hline & \multicolumn{2}{|c|}{$\begin{array}{c}\text { Piece of } \\
\text { Metal }\end{array}$} & \multicolumn{2}{|c|}{$\begin{array}{l}\text { Hand } \\
\text { Tools }\end{array}$} & \multicolumn{2}{|c|}{ Splinters } & \multicolumn{2}{|c|}{ Other } & \multicolumn{2}{|c|}{ Total } \\
\hline & No. & $\%$ & No. & $\%$ & No. & $\%$ & No. & $\%$ & No. & $\%$ \\
\hline $\begin{array}{l}\text { Knocking against } \\
\text { Hit by } \ldots \\
\text { Rubbing } \\
\text { Other } \\
\end{array}$ & $\begin{array}{r}24 \\
1 \\
-\end{array}$ & $\begin{array}{r}96 \\
4 \\
- \\
-\end{array}$ & $\begin{array}{r}4 \\
3 \\
11 \\
1\end{array}$ & $\begin{array}{r}21 \\
16 \\
58 \\
5\end{array}$ & $\begin{array}{l}19 \\
-\end{array}$ & $\frac{100}{-}$ & \begin{tabular}{r|}
10 \\
9 \\
1 \\
5
\end{tabular} & $\begin{array}{r}40 \\
36 \\
4 \\
20\end{array}$ & $\begin{array}{r}57 \\
13 \\
12 \\
6 \\
\end{array}$ & $\begin{array}{r}65 \\
15 \\
13 \\
7 \\
\end{array}$ \\
\hline Total & $\overline{25}$ & $\overline{100}$ & 19 & 100 & 19 & 100 & 25 & 100 & $\overline{88}$ & 100 \\
\hline
\end{tabular}

occurring at work, and it is interesting to find that $65 \%$ of the total number of these injuries occurred as a result of knocking the hand against something, usually a piece of rough metal or a splinter of wood, wire, or glass. A number of patients sustained tearing, cutting, or pinching injuries when the hand was hit by something falling on to it. Usually this type of accident occurred when goods were being handled, but three of the patients had hit themselves with a hammer. The other large category of injuries consisted of blisters. These most frequently occurred when the hand was rubbed against a tool handle for a considerable period of time. A blister resulted either when the tool handle was rough, or when, for some reason, the skin on the hand was soft. Amongst the injuries classified under "Other" were two burns.

Eighteen of the patients were injured away from work, mostly at home or in the garden. Ten of these men were in white-collar jobs. Wood splinters were responsible for five of the injuries, and five of the men blistered their hands while rowing, playing golf, or digging in the garden. The blisters all occurred in clerks and others not normally engaged in heavy manual labour, and this serves to illustrate the point, often made by the patients, that hands blister easily if strenuous manual work is undertaken when the skin on the hand is not hardened to rough work. This happened to labourers returning to their jobs after a holiday or a bout of illness, as well as to professional or clerical workers doing some unaccustomed manual labour.

\section{Intervals}

From Injury to First Treatment.-A point which is often stressed when prevention of infection is being considered is that workpeople should report to the first-aid room for every injury, no matter how trivial, since it is thought by some that immediate treatment of all injuries would considerably reduce the sepsis rate. It is therefore interesting to note that a high proportion of the patients with infected injuries did in fact report injury and receive treatment immediately after the accident. Out of a total of 106 patients with a known history of injury, $21(20 \%)$ received treatment straight away. The wound later became septic either during treatment (17 patients), or else the wound was treated once and was thought to need no further medical attention, but later symptoms of sepsis developed and the patient had to report again. Four more of the patients reported for treatment on the day of the injury, but as these patients waited for several hours before reporting, they have not been included in the above figures. Approximately half of the patients (55) reported for treatment within three days of the injury, and of the remaining 51 patients, 40 received treatment within two weeks of the injury.

From Onset of Symptoms to First Treatment.Table 4 shows the interval between the time when the hand first started to trouble the patient and his first treatment after he noticed the symptoms. Some of the patients with infected injuries developed symptoms while the injury was receiving treatment, and these patients have been classified under the heading "Being Treated".

It is clear from Table 4 that a large majority of the patients $(76 \%)$ reported for treatment either before the development of symptoms or within three days of the onset. The two groups of sepsis patients differ slightly in that there is a tendency for the nontraumatic group of patients to report for treatment rather lat:r than the others. This was not surprising since to the patient there would seem to be a greater chance of an infection clearing up by itself if it just came by itself without any injury to cause it. In the "Not Known" group were included patients who 
TABLE 4

NUMBER OF DAYS BETWEEN ONSET OF SYMPTOMS AND FIRST TREATMENT AFTER ONSET

\begin{tabular}{|c|c|c|c|c|c|c|}
\hline \multirow{3}{*}{ Number of Days } & \multicolumn{6}{|c|}{ Number of Patients } \\
\hline & \multicolumn{2}{|c|}{$\begin{array}{l}\text { Traumatic } \\
\text { Sepsis }\end{array}$} & \multicolumn{2}{|c|}{$\begin{array}{c}\text { Non- } \\
\text { traumatic } \\
\text { Sepsis }\end{array}$} & \multicolumn{2}{|c|}{ Total } \\
\hline & No. & $\%$ & No. & $\%$ & No. & $\%$ \\
\hline $\begin{array}{ll}\text { Being treated } \\
\text { No delay } & . \\
1-3 & . \\
4-9 & \ldots \\
10 \text { and over } & \ldots \\
\text { Not known } & \ldots\end{array}$ & $\begin{array}{r}19 \\
20 \\
48 \\
7 \\
12\end{array}$ & $\begin{array}{r}18 \\
19 \\
45 \\
7 \\
11\end{array}$ & $\begin{array}{r}6 \\
21 \\
13 \\
3 \\
2\end{array}$ & $\begin{array}{r}73 \\
47 \\
29 \\
7 \\
4\end{array}$ & $\begin{array}{r}19 \\
26 \\
69 \\
20 \\
3 \\
14\end{array}$ & $\begin{array}{r}13 \\
17 \\
46 \\
13 \\
2 \\
9\end{array}$ \\
\hline Total & 106 & 100 & 45 & 100 & 151 & 100 \\
\hline
\end{tabular}

either did not know the date of first treatment, or could not remember when the hand first started troubling.

From First Treatment to First Attendance at the Clinic.-Most of the patients had been receiving treatment from their general practitioner before attending the clinic, and on the whole they came to the clinic fairly soon after first reporting for treatment. Table 5 shows that over half the patients

TABLE 5

NUMBER OF DAYS BETWEEN FIRST TREATMENT AND FIRST ATTENDANCE AT THE CLINIC

\begin{tabular}{|c|c|c|c|c|c|c|c|}
\hline \multirow{3}{*}{\multicolumn{2}{|c|}{ Number of Days }} & \multicolumn{6}{|c|}{ Number of Patients } \\
\hline & & \multicolumn{2}{|c|}{$\begin{array}{c}\text { Traumatic } \\
\text { Sepsis }\end{array}$} & \multicolumn{2}{|c|}{$\begin{array}{c}\text { Non- } \\
\text { traumatic } \\
\text { Sepsis }\end{array}$} & \multicolumn{2}{|c|}{ Total } \\
\hline & & No. & $\%$ & No. & $\%$ & No. & $\%$ \\
\hline $\begin{array}{l}\text { No delay } \\
1-3 \quad \ldots \\
4-9 \quad \ldots \\
10 \text { or more }\end{array}$ & $\begin{array}{l}\cdots \\
\cdots \\
\cdots\end{array}$ & $\begin{array}{l}16 \\
47 \\
30 \\
13\end{array}$ & $\begin{array}{l}15 \\
44 \\
28 \\
13\end{array}$ & $\begin{array}{r}14 \\
13 \\
11 \\
7\end{array}$ & $\begin{array}{l}31 \\
29 \\
24 \\
16\end{array}$ & $\begin{array}{l}30 \\
60 \\
41 \\
20\end{array}$ & $\begin{array}{l}20 \\
40 \\
27 \\
13\end{array}$ \\
\hline Total & $\ldots$ & 106 & 100 & 45 & 100 & 151 & 100 \\
\hline
\end{tabular}

$(60 \%)$ were treated for three days or less before attending the clinic. Thirty of the patients $(20 \%)$ did not delay at all, but came straight up to the clinic immediately after reporting for treatment to their doctor or works first-aid room. Other patients were treated for periods ranging from about a week to a month or more before they came to the clinic.

A higher proportion of patients with no known history of injury attended the hospital without delay than did the others, but since these patients tended to wait longer before seeking treatment in the first place (Table 4), it is possible that by the time the patient reported to his doctor the infection was very severe. Table 6 bears this out since it suggests that, on the whole, the infection was longer established in the group of patients with no history of injury than in the traumatic group.
TABLE 6

DURATION OF SYMPTOMS BEFORE ATTENDANCE AT THE CLINIC

\begin{tabular}{|c|c|c|c|c|c|c|}
\hline \multirow{3}{*}{$\begin{array}{l}\text { Number of Days } \\
\text { before Attendance }\end{array}$} & \multicolumn{6}{|c|}{ Number of Patients } \\
\hline & \multicolumn{2}{|c|}{$\begin{array}{l}\text { Traumatic } \\
\text { Sepsis }\end{array}$} & \multicolumn{2}{|c|}{$\begin{array}{l}\text { Non- } \\
\text { traumatic } \\
\text { Sepsis }\end{array}$} & \multicolumn{2}{|c|}{ Total } \\
\hline & No. & $\%$ & No. & $\%$ & No. & $\%$ \\
\hline $\begin{array}{c}0-2 \\
3-4 \\
5-6 \\
7-8 \\
9 \text { or more }\end{array}$ & $\begin{array}{r}19 \\
37 \\
15 \\
4 \\
3\end{array}$ & $\begin{array}{r}25 \\
47 \\
19 \\
5 \\
4\end{array}$ & $\begin{array}{l}9 \\
8 \\
9 \\
9 \\
9\end{array}$ & $\begin{array}{l}20 \\
19 \\
20 \\
20 \\
20\end{array}$ & $\begin{array}{l}28 \\
45 \\
24 \\
13 \\
12\end{array}$ & $\begin{array}{l}23 \\
37 \\
20 \\
10 \\
10\end{array}$ \\
\hline Total & 78 & 100 & 44 & 99 & 122 & 100 \\
\hline
\end{tabular}

Duration of Symptoms before Attendance at the Clinic.-Twenty-nine of the patients could not remember how long they had had their symptoms before attending the hospital, and Table 6 shows the duration of symptoms for the 122 patients for whom this information is available. Of the total number of patients, rather more than half $(60 \%)$ attended within four days of the onset of symptoms, but there was a difference between the two groups of patients. Over two-thirds ( $72 \%)$ of the patients with a history of injury attended the hospital within four days of the onset of symptoms, whereas only just over a third $(39 \%)$ of the patients with no history of injury did so.

\section{The Cost of the Infection}

Length of Time Off Work.-From the economic point of view it is important to know how long the patient was off work, and whether he returned to his former employment. All the patients who were interviewed were given a form and asked to return it when they started work again, giving the date when they returned to work and stating if they had returned to the same or to a different job. This information was given by all but 13 of the patients. In addition, for various reasons, six of the patients were not working at the time of the enquiry. Information concerning the length of time the patients were off work was therefore available for 132 of the patients, and the data are set out in Table 7.

It is clear that the usual amount of time lost from work by patients in both groups was from two to four weeks, and 94 of the patients $(72 \%)$ were back at work within a month. A further 30 patients (22\%) were off for periods up to two months, and the remaining eight patients were off work for two to three months, the longest period of incapacity being 16 weeks (two patients). It was not possible to make an accurate estimate of working time lost in days, because some of the patients could only state approxi- 
TABLE 7

NUMBER OF WEEKS OFF WORK

\begin{tabular}{|c|c|c|c|c|c|c|}
\hline \multirow{3}{*}{$\begin{array}{l}\text { Weeks } \\
\text { Off Work* }\end{array}$} & \multicolumn{6}{|c|}{ Number of Patients } \\
\hline & \multicolumn{2}{|c|}{$\begin{array}{c}\text { Traumatic } \\
\text { Sepsis }\end{array}$} & \multicolumn{2}{|c|}{$\begin{array}{l}\text { Non- } \\
\text { traumatic } \\
\text { Sepsis }\end{array}$} & \multicolumn{2}{|c|}{ Total } \\
\hline & No. & $\%$ & No. & $\%$ & No. & $\%$ \\
\hline $\begin{array}{c}1 \\
2 \\
3 \\
4 \\
5 \\
6 \\
7 \\
8 \\
9 \text { or more }\end{array}$ & $\begin{array}{r}8 \\
27 \\
18 \\
15 \\
7 \\
4 \\
5 \\
2 \\
7\end{array}$ & $\begin{array}{r}9 \\
29 \\
19 \\
16 \\
8 \\
4 \\
5 \\
2 \\
8\end{array}$ & $\begin{array}{r}5 \\
11 \\
6 \\
4 \\
5 \\
3 \\
3 \\
1 \\
1\end{array}$ & $\begin{array}{r}12 \\
28 \\
15 \\
10 \\
13 \\
8 \\
8 \\
3 \\
3\end{array}$ & $\begin{array}{r}13 \\
38 \\
24 \\
19 \\
12 \\
7 \\
8 \\
3 \\
8\end{array}$ & $\begin{array}{r}10 \\
29 \\
18 \\
15 \\
9 \\
5 \\
6 \\
2 \\
6\end{array}$ \\
\hline Total & 93 & 100 & 39 & 100 & 132 & 100 \\
\hline
\end{tabular}

* Fractions of a complete week are reckoned as a complete week.

mately how long they were off work, but a rough average was about 24 days. If the eight patients who were off work for eight weeks or more are omitted from the calculations, the average time lost is reduced to 20 days.

Residual Disability.-It was not possible to obtain much information concerning residual disability, but it is known that seven of the patients returned to different jobs. This change did not always have anything to do with the hand infection. One boy was called up into the Army, another boy took up the apprenticeship he had been waiting for, and another patient, a miner, changed from datal (day rate) work to piece work, as the opportunity to do so presented itself at that time. One of the men reported that he had been on light work for two weeks while his hand hardened and then returned to his old job. Two of the men, a builder's labourer and a coal hewer, reported that although they had returned to their old jobs, after a week or so at work the hand was still tender and sore at times. One patient, a datal worker in the pits, was off work for three to four months with a subcutaneous infection of the right palm, and found that he could not do his jobputting up timber and general repair work-when he returned to the pit. He was then given a slightly lighter job, at a little less money, but that, too, was difficult for him, and when he was visited nearly a year after his injury he said he had lost a lot of time from work because of his hand. He was at that time off work because of another injury to his hand, and he said that he wanted work either on the surface or in a factory tecause there was a shortage of suitable light jobs down his pit.

A very large majority of the patients returned to their old jobs, and several of them wrote to say that the hand had healed well and had given no more trouble.
Financial Cost.-A rough idea of the alteration to the patients' incomes because of their incapacity can be seen from Table 8 . It has only been possible to make a rough estimate of any alteration in the patient's financial circumstances, and the data take into account no more than the difference between the patient's average earnings at the time when he stopped work, and his personal income from Sickness Benefit, Injury Benefit, or other insurance benefits while he was off work. No note was taken of expenditure or the earnings of his family or any refund of Income Tax, because these were considered to be personal matters which the patient should not be expected to divulge.

The amounts lost each week by the patients varied enormously, and for the most part the losses ranged from $£ 1$ to $£ 7$ a week. This partly reflects the disparity between the wage rates in different occupations and age groups, and partly the different insurance payments paid to patients drawing Sickness Benefit and patients drawing Injury Benefit. Also, some patients had more dependants than others and therefore drew more in insurance allowances. Some of the patients drew allowances from their trade union or works sick or accident fund, and in some cases wages were made up by the employer, although the man might still stand to lose his overtime or bonus. The general picture given by Table 8 is

TABLE 8

DIFFERENCE BETWEEN USUAL EARNINGS AND INCOME DURING ILLNESS

\begin{tabular}{|c|c|c|c|c|c|c|c|}
\hline \multirow{3}{*}{\multicolumn{2}{|c|}{ Weekly Loss }} & \multicolumn{6}{|c|}{ Number of Patients } \\
\hline & & \multicolumn{2}{|c|}{$\underset{\text { Sepsis }}{\text { Traumatic }}$} & \multicolumn{2}{|c|}{$\begin{array}{l}\text { Non- } \\
\text { traumatic } \\
\text { Sepsis }\end{array}$} & \multicolumn{2}{|c|}{ Total } \\
\hline & & No. & $\%$ & No. & $\%$ & No. & $\%$ \\
\hline $\begin{array}{l}\text { No change } \\
\text { Less than } £ 1 \\
£ 1-£ 1 \quad 190 \\
£ 2-£ 2 \quad 190 \\
£ 3-£ 3 \quad 190 \\
£ 4-£ 4190 \\
£ 5-£ 5190 \\
£ 6-£ 6190 \\
£ 7-£ 7190 \\
£ 8 \text { and over } \\
\text { Other } \quad .\end{array}$ & $\begin{array}{l}\ldots \\
\ldots \\
\ldots \\
\ldots \\
\ldots \\
\ldots \\
\ldots \\
\ldots\end{array}$ & $\begin{array}{r}12 \\
4 \\
13 \\
14 \\
14 \\
10 \\
13 \\
12 \\
5 \\
8 \\
1\end{array}$ & $\begin{array}{r}11 \\
4 \\
12 \\
13 \\
13 \\
10 \\
12 \\
11 \\
5 \\
8 \\
1\end{array}$ & $\begin{array}{r}13 \\
1 \\
6 \\
5 \\
4 \\
9 \\
1 \\
3 \\
1 \\
2 \\
\end{array}$ & $\begin{array}{r}29 \\
2 \\
13 \\
11 \\
9 \\
20 \\
2 \\
7 \\
2 \\
5 \\
\end{array}$ & $\begin{array}{r}25 \\
5 \\
19 \\
19 \\
18 \\
19 \\
14 \\
15 \\
6 \\
10 \\
1\end{array}$ & $\begin{array}{r}16 \\
3 \\
13 \\
13 \\
13 \\
12 \\
13 \\
9 \\
10 \\
10 \\
4 \\
6 \\
1\end{array}$ \\
\hline Total. . & $\ldots$ & 106 & 100 & 45 & 100 & 151 & 100 \\
\hline
\end{tabular}

that the loss varied around a mid-point of about $£ 310$ s. a week, with a few patients losing $£ 1$ or less at one extreme and over $£ 8$ at the other. Twentyfive patients reported no alteration in income while they were off work, and this group included the unemployed, the retired, students, members of the Armed Forces, and those whose salary or wage was made up without loss. One man, classified under 
"Other" did in fact lose heavily, but it was impossible to estimate the loss on a weekly basis. This man had a smallholding where he grew potatoes and cabbages, and there was no one to do the work for him while he was attending the clinic. His work was seasonal and while he might take $£ 10$ to $£ 12$ a week for six months or so, there were always times when his earned income was nil. Unfortunately the infection, acute paronychia of the left thumb, developed at the worst time for him, which was the middle of June when he was just about to plant out his summer and winter cabbages. He was off work for about a month because he could not hold anything in his hand. This made him a month late in doing his planting, and, to add to his troubles, September came in frosty with the result that he " may as well never bothered putting any out". The cost to this patient could not be estimated exactly, but he wrote at the end of November to say that he thought he would have lost at least $£ 150$.

\section{Social and Occupational Factors Concerned in the Development of Sepsis}

It was clear both from the statements made by the patients and also from observation of the state of their hands that their hands had often received small cuts and trivial puncture wounds, but according to the patients the majority of these wounds did not become septic. The question is, Why do some wounds become septic when others do not? Also, are there any social factors which might cause infection to develop when there has been no apparent injury?

Some of the factors which may affect the development of sepsis, such as the condition of the hand at the time of injury, and the type of treatment received, are of concern to the surgeon, and they are not considered here. The emphasis here has been placed on the social and occupational factors only.

It was not possible to make an exact quantitative assessment of these factors, and the evidence is based on the statements made by the patients in the course of discussions on their particular hand infections, and also on the problem of industrial sepsis in general. Although the results in this section are qualitative, no conclusions are based on isolated instances or on very small numbers.

General Health of the Patients.-The patient's state of health at the time of the onset of sepsis is an important factor to consider. The patients were asked if they had had any illnesses during the previous three months or so sufficiently severe to keep them away from work, and also whether they thought the onset of infection had anything to do with their general health. The trauma group of patients were also asked about their general health, with the explanation that the question was asked because of the possible relationship between the health of the worker and his susceptibility to accidents. It was made clear to all the patients that the purpose of this question was to find a possible cause of their accident or infection, and that it did not refer to their feelings after the injury had happened or sepsis had developed. It was thought worthwhile to compare the findings of the two groups, and these have been analysed in Table 9. No great exactness is

TABLE 9

STATE OF HEALTH OF THE PATIENTS

\begin{tabular}{|c|c|c|c|c|c|c|c|c|}
\hline \multirow{4}{*}{$\begin{array}{l}\text { State of Health } \\
\text { before Present } \\
\text { Illness }\end{array}$} & \multicolumn{8}{|c|}{ Number of Patients } \\
\hline & \multicolumn{6}{|c|}{ Sepsis } & \multirow{2}{*}{\multicolumn{2}{|c|}{$\begin{array}{c}\text { Trauma } \\
\text { Total }\end{array}$}} \\
\hline & \multicolumn{2}{|c|}{ Traumatic } & \multicolumn{2}{|c|}{$\begin{array}{c}\text { Non- } \\
\text { traumatic }\end{array}$} & \multicolumn{2}{|c|}{ Total } & & \\
\hline & No. & $\%$ & No. & $\%$ & No. & $\%$ & No. & $\%$ \\
\hline $\begin{array}{l}\text { Recent illness* . } \\
\text { Run down } \\
\text { Fit and no illness }\end{array}$ & $\begin{array}{r}3 \\
26 \\
77\end{array}$ & $\begin{array}{r}3 \\
24 \\
73\end{array}$ & $\begin{array}{r}5 \\
13 \\
27\end{array}$ & $\begin{array}{l}11 \\
29 \\
60\end{array}$ & $\begin{array}{r}8 \\
39 \\
104\end{array}$ & $\begin{array}{r}5 \\
26 \\
69\end{array}$ & $\begin{array}{r}25 \\
8 \\
264\end{array}$ & $\begin{array}{r}8 \\
3 \\
89\end{array}$ \\
\hline Total & 106 & 100 & 45 & 100 & 151 & 100 & 297 & 100 \\
\hline
\end{tabular}

* " Recent illness" means any illness during approximately three months before the interview and which caused the patient to lose time from work.

claimed for this Table, chiefly because it is possible that the patients in the sepsis group may have been more ready with their answers because they had, perhaps, already considered the question.

It will be seen from this Table that nearly a third of the sepsis group of patients $(31 \%)$ had some illness or " run down" condition to report, whereas the trauma group of patients had a much cleaner bill of health; all but $11 \%$ of the trauma group of patients felt fit at the time of injury and had been clear of incapacitating illness for at least three months before the interview. Another noticeable difference between the two groups of patients was that there were more " run down" conditions in the sepsis group than in the trauma group. Of the total number of patients with infections, over a quarter (26\%) complained of a feeling of unfitness at the time of the onset of sepsis, but only $3 \%$ of the trauma group of patients said that they were not feeling fit at the time of the injury.

The term " run down" is a vague one, and when the patients mentioned it they were asked if they had any symptoms in support of this feeling. The most frequently mentioned trouble was boils, and several of the patients mentioned constant sore throats and an inability to throw off colds. Others had no physical symptoms but said that they always felt tired and did not feel like doing anything much after working hours. Two of the men were attending 
their doctors because they felt in need of a tonic, and one man had just taken a week off work because he did not feel well. A few of the patients were unmarried and living in lodgings, and some of these patients complained of inadequate food and loss of weight.

The illnesses mentioned by the patients were too varied to classify, but the most frequently mentioned complaints were stomach troubles and chest troubles.

Twenty-four of the sepsis group of patients had had septic conditions of some kind, usually to the hand, within the previous two years. Although this may be a reflexion of the job rather than of the man, it is not too fanciful to suppose that some people are more prone to sepsis than others. As one patient remarked, "With me every scratch turns septic."

\section{Reasons for Delay in Seeking First Treatment}

Neglect.-On the whole the patients did not wait an unreasonable amount of time before seeking treatment. Forty-five of the patients $(30 \%)$ reported for first treatment either immediately after the injury or as soon as the hand started to trouble them. For these patients the question of neglect does not arise, unless it is always considered neglectful to wait for an injury to become infected before reporting it. The remaining 106 patients waited for at least one day after the onset of symptoms before seeking treatment. The reason given for the delay was usually that when the hand started to trouble them it did not seem to be worth bothering about, and the patients hoped that if they treated the hand themselves the infection would clear up. It was only when the hand became really painful that these patients considered a visit to the doctor to be justified. This attitude is easy to criticize until it is remembered that for the patient a visit to the doctor can be a tedious and time-consuming business. There was the feeling, too, that the doctor might not give a favourable reception to a patient who took up his time with a trivial complaint like a sore finger. A few of the patients had obviously gone on hoping for the best for too long after they might reasonably have been expected to seek expert attention, but in no case did a patient put up with a painful or throbbing hand for more than two or three days. Such delay as there was occurred when the hand was merely sore or red looking. Usually when a patient had waited more than four or five days before seeking treatment it was either because the infection seemed to have cleared up but had broken out again, or else the infection had been slow in developing. Treatment given at home was mostly bathing or poulticing, but a few of the patients squeezed the wound to bring it to a head, or explored it with a needle or a pin in search of a foreign body.

The Week-end.-A suggestion is made by the Chief Factory Inspector in his Annual Report for 1950 that the week-end plays a part in the development of sepsis. The evidence here supports this suggestion. Twenty-six of the patients said that they would have gone to their doctor earlier had it not been for the week-end. This happened when the injury occurred or the sepsis developed on Friday or Saturday, but the patient did not attend for treatment until Monday, or when the hand had been treated on Thursday or Friday but became worse over the week-end and the patient did not attend for further treatment until Monday. These patients said that they did not like to bother their doctors over the week-end unless it was absolutely necessary; nor did they want to disturb their own week-end break. Works first-aid departments are often closed on Sundays, and sometimes the patient's doctor had no Sunday surgery, so that, in some cases, for the patient to have obtained medical attention on a Sunday would have required real effort.

The Materials Involved.-The large number of occupations involved and the variety of materials handled by the patients made the agents difficult to classify. In general the type of injury was more important than the agent causing the injury, and it seems that hand infections may develop amongst workers in any occupation where the workers are liable to receive small cuts and blisters. This is consistent with the bacteriological findings of Williams and Miles (1949), who showed that the source of the bacteria which cause wound infection is often the patient's skin or nose, and that there is little likelihood of contamination directly from the wounding agent.

First-Aid Facilities.-The fall in the industrial sepsis rate in recent years can be partly attributed to improved methods of treatment, the growth of the industrial health services and better first-aid facilities in industry, but unfortunately the standard of treatment and the provision of first-aid facilities is not uniformly good throughout industry.

The patients were asked to say what they thought of the first-aid facilities provided at their place of work, and most of them either had no particular comment to make or else they were very well satisfied with the first-aid attendance and facilities. Satisfaction was most often expressed by the miners and by people working for large firms. With one exception, all the patients in work covered by the regulations said that some kind of first-aid facilities 
were provided, but there was not always a responsible person in charge, and even the trained attendants were sometimes criticized for the treatment they had given the patient. The exception was a builder's plasterer who said that there was supposed to be a first-aid box on the job, but when there was one it was usually empty. Often patients did not know of any person appointed to be in charge of the first-aid box, and in some firms the routine after receiving a small injury seems to be for the injured workman to help himself to the contents of the first-aid box, and he then either dresses the wound himself or else he finds a workmate or clerk to do it for him.

\section{Prevention}

There is no simple solution to the problem of industrial sepsis. Prevention can be considered from three points of view ; first, prevent the injury from occurring ; secondly, protect the worker ; and thirdly, improve the treatment.

The small injuries which become septic are brought about in a variety of ways, so that no one remedy can be very effective. Small metal filings are an obvious source of small puncture wounds, and to design machines which do not expose workers to injuries of this sort is a problem for the research engineer.

Since many of the injuries are caused by knocking the hand against something sharp, it should be possible to reduce the sepsis rate by eliminating the objects which may scratch and produce small injuries. Protruding nails can be knocked in or pulled out, rough metal edges filed down, and wire rope kept in good condition.

When tools are considered it is obvious that one way to reduce the danger of injury is by the correct use of the right tool. Workers sometimes use a defective tool as, for example, a hammer with a wobbly head, and this can lead to injury. Sometimes the tool is defective without the worker knowing about it, as in the case of a man who was injured by a piece of soft metal flying off the edge of a hammer head. The use of hand tools calls for the worker's full attention, and several injuries were caused by the worker allowing his attention to be distracted when he was using a hand tool. One point made by several patients was the importance of having a smooth handle on the tool. Constant rubbing against a rough, unvarnished, wood handle can easily cause a blister.

The use of protective clothing is a particularly relevant consideration, since many small injuries could be prevented if the worker wore safety gloves. There is still a certain amount of resistance to the use of all forms of protective clothing, and on the whole the patients did not take kindly to the idea of wearing gloves. This resistance can be attributed in part, no doubt, to the mind's dislike of any strange idea and to a natural conservatism by no means confined to industry. But the use of safety gloves is open to one special objection and this is that, unlike other articles of protective clothing, the use of gloves interferes with one very important function of the protected part. Safety gloves, if they cover the whole hand, impair the wearer's sense of touch. Many of the patients said that if they wear gloves they feel, literally, out of touch with the job because their hands are made to feel clumsy and incompetent, and they lose the feel of their fingers. Another objection was that gloves are dangerous because they are liable to catch in things, especially in moving machinery; or they may slip in the process of throwing materials or goods as, for example, when a foundry worker is throwing metal into a furnace. Miners said that gloves make the hands too hot, and are unpleasant to wear if the pit is wet. Complaints were frequently made about the quality and the cost of the gloves offered. The gloves provided at work were said to be clumsy, ill fitting and without variety of style or size. The leather was said to be too hard, and hands are hurt when the rough part of the leather is on the inside of the glove. Also, the usual cost of leather gloves is about 8s. 6d. (although some firms issue them free), and it is said that they do not last for more than two or three weeks of hard wear. When due allowance has been made for valid reasons for not wearing safety gloves, it does seem that there is an unsatisfied demand for gloves of good material, made to fit the wearer, and suited to the job he does. Manufacturers of safety gloves in this country have put much thought into the problem of making good industrial gloves, and a wide variety of styles is made. Knowledge of the range of gloves available is not, perhaps, sufficiently widespread, and it is certain that there are bad industrial gloves on the market as well as good ones.

The third way of preventing industrial sepsis, as mentioned earlier, is by the improvement of first-aid treatment. One suggested method of doing this is to place the burden of responsibility on the worker, by instructing him to report every injury, however trivial, to the first-aid room. Williams and Capel (1945) made a study of this particular question, and they doubted whether the surgery treatment of all small injuries would materially reduce the incidence of industrial sepsis, because in the factories studied by them very few ( 1 to $2 \%$ ) of the untreated wounds became septic. Furthermore, they estimated that 
the surgery treatment of all trivial cuts-even if the workers could be induced to attend-would demand a five to tenfold increase in surgery staff and accommodation and would lead to an intolerable loss of working time. These conclusions are supported by the results of this study. Sixty-six of the patients (44\%) would not have been helped by a system of reporting every injury, because these patients either had no known injury to report $(30 \%)$, or else they did in fact report the injury straight away. Furthermore, the patients said that they were always cutting, scratching, and knocking their hands, and if all these injuries were reported an enormous amount of working time would be lost. As one man expressed it, " If I reported everything, I might just as well sit in the accident room all day."

It must be admitted that it is not always easy to provide good first-aid facilities, especially in the building trades where workers move about between sites, and in the shipyards where the layout makes it difficult for a first-aid room to be within easy access of all workers. Nevertheless, the evidence indicates that more might be done to improve first-aid facilities, and to educate first-aid attendants in the treatment of infections of the hand.

\section{Discussion}

The problem of wound infection is of national importance in view of its frequency and of its cost, both to the community and to the individual. It is very difficult to obtain even an approximate idea of the extent of sepsis in industry, but it is clear that although the arrival of antibiotics has greatly improved the outlook, a high proportion of industrial injuries become septic, and sepsis is responsible for a great deal of time lost from work. In addition, as far as hand infections are concerned, many patients with severe sepsis are left with some measure of disability (Robins, 1952).

The most comprehensive of the available figures are those given by the Chief Inspector of Factories in his annual reports (1950). These figures show that for 20 years or so before 1948 the proportion of compensation accidents due to sepsis varied between 10 and $12 \%$ of the total number of accidents. But the proportion of septic injuries has decreased steadily since 1948 and by 1951 the figure had dropped to $7 \cdot 3 \%$. In spite of this decrease, the figure is still high and in 1951 a total of 13,470 sepsis cases was reported and sepsis accounted for one death. These figures only include cases of industrial sepsis reported after sepsis had developed, and causing four or more days' absence from work. They make no allowance for injuries becoming septic after notification, or for cases of sepsis which have no history of injury and are not of proved occupational origin. The true incidence of industrial sepsis is probably much higher, and the figures will vary considerably in different occupations. In 1950 it was estimated that in the engineering industries in the Midlands sepsis caused between 10 and $30 \%$ of lost time accidents, and a corresponding proportion of time lost. Bull (1950), in a study of a light engineering factory, showed that in 1946 septic injuries caused $29 \%$ of all compensation accidents occurring in this factory, and $23 \%$ of the total time lost from work. The mean time-loss per injury for sepsis in this factory in 1946 was 25 days, but in 1948, after advances in treatment had been introduced, this figure was reduced to 17 days. In the present study the average time lost from work was about 24 days, but it should be remembered that for the most part these infections were well established and the subjects had to attend hospital. These facts make comparison between Bull's and the present series less illuminating than if both series had been of subjects attending factory medical departments.

The Ministry of National Insurance does not keep separate figures showing the amount paid out in benefits on account of industrial sepsis, but it is clear from the above figures that the cost to the community in terms of insurance payments made and production lost must be considerable.

\section{Summary}

The aims of the research were first, to find out how much time and money were lost through hand infections ; secondly, to assess the part played by occupational and social factors in the origin of infections of the hand; and thirdly, to suggest how these infections might be prevented.

The patients interviewed were attending the hand clinic of the Department of Surgery in the Royal Victoria Infirmary, Newcastle-upon-Tyne. One hundred and fifty-one patients with infected hands were interviewed during the period from March, 1952, until December, 1952. Forty-five of these patients $(30 \%)$ had no known history of injury. There was no selection of patients for interview ; during the weeks of interview all the new patients were seen.

Forty per cent. of the patients were either miners or engineers, and a further $22 \%$ were workers in transport or building or unskilled occupations. The remaining patients worked in a variety of occupations.

Sixty-five per cent of the injuries at work occurred as a result of knocking the hand against something. Other patients were usually hit by falling bodies, or blistered their hands by constant rubbing against tools. 
Twenty per cent. of the patients with infected injuries had received treatment straight away, and $76 \%$ of the total number of patients reported for treatment either before the onset of symptoms or within three days of the onset.

The patients were usually off work for two to four weeks, and nearly three-quarters of the patients were back at work within a month. All but seven returned to their former employment.

Factors mentioned by the patients as possible part causes of their infections were poor general health, delay in seeking first treatment brought about by neglect or the intervention of the week-end, and inadequate first-aid facilities. The wounding agent was not considered important as a source of infection.

The prevention of trivial injuries, the use of hand tools, and the use of safety gloves are discussed. It is suggested that more might be done to improve the standard of first-aid treatment of hand infections.
It is considered that it is not worth while to insist on the immediate treatment of every trivial injury.

I wish to thank Professor R. C. Browne for his advice and general help throughout the work, and also to acknowledge the statistical assistance given by $\mathrm{Mr}$. $\mathrm{H}$. Campbell and Mr. D. Newell. The work was made possible by the help and interest received from the staff and patients of the hand clinic of the Department of Surgery in the Royal Victoria Infirmary, Newcastleupon-Tyne. I am also greatly indebted to Mrs. $M$. Berry for secretarial assistance, and to Mrs. D. Weightman for her help with the calculations.

\section{REFERENCES}

Bull, J. P. (1950). Brit. med. Bull., 7, 69.

General Register Office (1951). Classification of Occupations, 1950, H.M. Stationery Office, London.

Ministry of Stanery of the Chief Inspector of Factories. H.M. Stationery Office,

London.
Robins, R. H. C. (1952). J. Bone Jt Surg., 34-B, 567.

Williams, R. E. O., and Capel, E. H. (1945). British Journal of Industrial Medicine, 2, 217.

, and Miles, A. A. (1949). "Infection and Sepsis in Industrial Wounds of the Hand." Spec. Rep. Ser. med. Res. Cour., Lond., No. 266. 